\title{
Should anosmia and dysgeusia be a concern for oral and maxillofacial surgeons during the COVID-19 pandemic?
}

\author{
Hamad Alharbi ${ }^{1,2} \cdot$ Sijia You $^{3} \cdot$ Joseph Katz ${ }^{4}$ \\ Received: 27 October 2020 / Accepted: 18 April 2021 / Published online: 5 May 2021 \\ (c) The Author(s), under exclusive licence to Springer-Verlag GmbH Germany, part of Springer Nature 2021
}

\begin{abstract}
Purpose Dysgeusia and anosmia have been liked to COVID-19 infection. The aim of this study is to study the prevalence of dysgeusia and anosmia in COVID-19 patients treated at the University of Florida Health Center and establish the odds of having an olfactory and gustatory disorder with a confirmed COVID-19 infection.

Methods This is a retrospective cross-sectional study utilizing the University of Florida Health Center patients' registry i2b2 platform to search for ICD 10 diagnoses of COVID-19 infection and taste and smell disturbances. We assessed the odds ratio for patients with dysgeusia and anosmia having a laboratory-confirmed COVID-19 infection using a logistic regression model adjusting for gender, race, age, and comorbidity conditions. $P<0.05$ was deemed significant.

Results Out of 889 individuals that tested positive for COVID-19, 12.88\% were diagnosed with taste and smell disturbances. The odds ratio for COVID-19 for people with dysgeusia and anosmia was 39.107. After adjusting for sex, age, and race, it was $41.9,37$, and 34.2 , respectively.

Conclusion Taste and smell disturbances in COVID-19 are not anecdotal. It is paramount that oral and maxillofacial surgeons include taste and smell disturbances in the history and physical examination as these symptoms are suspicious of active COVID-19 infection. Patients presenting with an olfactory and gustatory disorder should undergo further evaluations for COVID-19 infection and oral and maxillofacial surgeons should enhance the personal protective equipment used when treating these patients to prevent further spread of the infection and protect other healthcare members.
\end{abstract}

Keywords COVID-19 $\cdot$ Dysgeusia $\cdot$ Anosmia $\cdot$ Taste disturbance $\cdot$ Smell Disturbance

\section{Introduction}

The outbreak of novel coronavirus (COVID-19) or severe acute respiratory syndrome coronavirus 2 (SARS-CoV2) infected disease began in Wuhan, Hubei Province, China, in December 2019 [1]. Two months later, In February 2020, the World Health Organization named the disease as a novel coronavirus COVID-19. Since then, the disease has spread globally and become a pandemic with an urgent threat to global health and a massive impact on economic stability [2].

Human to human transmission of SARS-CoV-2 has been confirmed [3], through the infected fluid droplets secreted by infected individuals' respiratory system.

Studies showed that physicians could be at risk of COVID-19 infection [4, 5]. Oral and maxillofacial surgeons, especially, are at increased risk of COVID-19 infection. This profession requires close contact with the patients during physical examinations, especially given the high risk of 
encountering aerosolized viral particles while using instruments to examine and treat the oral cavity.

Therefore, it is crucial to identify high predictive signs and symptoms, where it could be used as a diagnostic tool for COVID-19 and diagnose the disease earlier, especially in asymptomatic patients with only dysgeusia and anosmia, thus, cutting off the route of transmission and protecting the physicians.

The most common clinical findings of confirmed cases of COVID-19 are those associated with lower respiratory tract infection, including fever, cough, shortness of breath, and abnormal chest CT. Other common symptoms include myalgia, tiredness, stomach pain, nausea, diarrhea, and vomiting. Recent studies have also shown that COVID-19 patients may develop neurologic symptoms, which may range from major events like impaired consciousness, acute cerebrovascular diseases, skeletal muscle injury, or minor effects like dysgeusia and anosmia [6-8].

Multiple reports have been published about the prevalence of dysgeusia and anosmia among COVID-19 patients since the pandemic started [9-23]. The incidence of loss of smell in COVID-19 patients varied widely among these studies, ranging from $33.9 \%$ to $68 \%$ [16]. In some cases, anosmia was the only symptom of COVID 19 [24].

The aim of this study is to study the true prevalence of dysgeusia and anosmia in COVID-19 patients and determine if this association should be a concern for oral and maxillofacial surgeons during the pandemic as it could be a clue for the diagnosis of COVID-19?

If the results shows a significant association between dysgeusia and anosmia in COVID-19, then oral and maxillofacial surgeons should be informed and educated about the importance of including taste and smell disturbances in the history and physical examination as dysgeusia and anosmia could be a clue for the diagnosis of COVID-19.

\section{Material and methods}

In this retrospective cross-sectional study, we used the University of Florida (UF) Health Office of the Chief Data Officer i $2 b 2$ platform and the UF Integrated Data Repository (IDR) which is a large-scale database used to collect, store, and report on information from across UF Health's clinical and research enterprises. Patients' protected health information has been de-identified. For this reason, this study was exempt from approval by the IRB. Data were collected from June 2015 to April 2020. The study population was obtained from the outpatient and inpatient episodes of care at UF Health Centers across Florida. The subjects were selected utilizing the tenth edition of the International Classification of Diseases (ICD-10) and they had a diagnosis of COVID-19
(ICD 10-R43) and Disturbances of Smell and Taste (ICD 10-R43). The total patient population visiting the different departments and the IDR provided their age and sex distribution. The prevalence ratios were used to compare rates between groups. Health Office of the Chief Data Officer provided the analytic data set, and the odds ratio (OR) for the association was calculated by logistic regression using SAS statistical software. The $95 \%$ confidence interval (CI) and $P$-value for each OR were tabulated. $p<0.05$ was deemed significant.

\section{Results}

A total hospital population of 987,849 attended the different UF Health centers across Florida in the period from June 2015 to September 2020 was included in this study. Of these, 1324 cases had taste and smell disturbances. A total of 889 individuals tested positive for COVID-19.

In this subset, $12.88 \%$ tested positive for COVID-19 were also diagnosed with loss of taste and smell by their physicians.

Table 1 demonstrates the patient's characteristics and demographics between the three groups in our study: (1) control, (2) all COVID-19 patients, and (3) patients with loss of smell and taste, and COVID-19. Out of the 889 confirmed COVID-19 patients, 114 patients had taste and smell disturbances, of which 59 were female and 55 males. Within the COVID-19 group, $45 \%$ were White population, and $25.6 \%$ were African American, while in the group of patients with both COVID-19 and taste and smell disturbances, $60 \%$ were White, and $17.7 \%$ were African American. Based on the age, $39.9 \%$ from the COVID-19 were at the age group 18-34 years while $68.8 \%$ of the patients with both COVID-19 and taste and smell disturbances lies within the age group 18-34 years.

The odds ratio for having COVID-19 for people with taste and smell was 39.107 before adjustments. After adjusting for sex and age, and race, it was 41.9, 37, and 34.2, respectively.

The OR for taste and smell disturbances after adjustment for comorbidities, diabetes, respiratory diseases, cardiovascular, and obesity was $31.4,13.4,24.6$, and 24.0 , respectively (Table 2).

\section{Discussion}

The aim of this study is to study the prevalence of dysgeusia and anosmia in COVID-19 patients and to establish the odds of having an olfactory and gustatory disorder with a confirmed COVID-19 infection.

In this study, we found that the odds ratio for having COVID-19 in people with taste and smell disturbances was 39.107 , which is a significantly higher number compared 
Table 1 Patients characteristics and demographic between control, COVID-19, and loss of smell and taste in COVID-19 patient groups

\begin{tabular}{llll}
\hline & $\begin{array}{l}\text { COVID-19 with taste and smell } \\
\text { disturbances }\end{array}$ & $\begin{array}{l}\text { COVID-19 } \\
\text { patients }\end{array}$ & Hospital Population \\
\hline Total population & 114 & 889 & 987,849 \\
Female & 59 & 509 & 532,391 \\
Male & 55 & 386 & 455,458 \\
Female/male & 1.07 & 1.32 & 1.16 \\
African American, $\%$ & $17.7 \%$ & $25.6 \%$ & $11.3 \%$ \\
Asian, $\%$ & 0 & $2.8 \%$ & $1.9 \%$ \\
White & $60 \%$ & $45 \%$ & $50 \%$ \\
Ages 0-9 & 0 & $1.9 \%$ & $9.2 \%$ \\
Ages 10-17 & 2 & $2.47 \%$ & $6.7 \%$ \\
Ages 18-34 & 68.8 & $39.9 \%$ & $21.5 \%$ \\
Ages 35-44 & $20 \%$ & $11.1 \%$ & $9.6 \%$ \\
$45-54$ & 4.2 & $1.2 \%$ & $10.8 \%$ \\
$55-64$ & 3 & $11.2 \%$ & $15.6 \%$ \\
$65-74$ & 1 & $12.3 \%$ & $14.6 \%$ \\
$74-85$ & 1 & $6.5 \%$ & $8.5 \%$ \\
\hline
\end{tabular}

to a study by Menni et al. [13] which reported OR of 6.59 for anosmia and ageusia and by Yan et. al. [14] which reported 10.9 for anosmia and 11.9 for ageusia.

Table 2 Odds ratio with and without adjustments for age, sex, race, and comorbidities

\begin{tabular}{|c|c|c|c|c|}
\hline \multirow[b]{2}{*}{ Taste vs. non-taste ${ }^{1}$} & \multirow{2}{*}{$\begin{array}{l}\begin{array}{l}\text { Odds } \\
\text { ratio }\end{array} \\
39.107\end{array}$} & \multicolumn{2}{|c|}{$\begin{array}{l}95 \% \text { Wald confidence } \\
\text { limits }\end{array}$} & \multirow{2}{*}{$\begin{array}{l}P \text {-Value } \\
<0.0001\end{array}$} \\
\hline & & 27.367 & 55.885 & \\
\hline Taste vs. non-taste ${ }^{1}$ & 41.852 & 30.411 & 57.598 & $<0.0001$ \\
\hline Male vs female & 0.847 & 0.735 & 0.976 & 0.022 \\
\hline Taste vs. non- taste ${ }^{2}$ & 37.239 & 26.035 & 53.265 & $<0.0001$ \\
\hline Age $18-34$ vs $0-17$ & 6.565 & 4.658 & 9.251 & $<0.0001$ \\
\hline Age $>34$ vs $0-17$ & 3.156 & 2.249 & 4.427 & 0.0343 \\
\hline Taste vs. non-taste ${ }^{3}$ & 34.48 & 24.323 & 48.881 & $<0.0001$ \\
\hline Race Black vs. White & 2.683 & 2.28 & 3.157 & $<0.0001$ \\
\hline Race other vs. White & 1.13 & 0.965 & 1.323 & $<0.0001$ \\
\hline Taste vs. non-taste ${ }^{4}$ & 13.744 & 9.582 & 19.714 & $<0.0001$ \\
\hline Respiratory vs. non-respiratory & 8.358 & 7.268 & 9.611 & $<0.0001$ \\
\hline Taste vs. non-taste ${ }^{5}$ & 20.947 & 14.58 & 30.094 & $<0.0001$ \\
\hline Endocrine vs. non-endocrine & 3.865 & 3.38 & 4.419 & $<0.0001$ \\
\hline Taste vs. non-taste ${ }^{6}$ & 24.043 & 16.7 & 34.615 & $<0.0001$ \\
\hline Obese vs. non-obese & 5.31 & 4.564 & 6.177 & $<0.0001$ \\
\hline Taste vs. non-taste ${ }^{7}$ & 31.407 & 21.872 & 45.099 & $<0.0001$ \\
\hline Diabetes vs. non-diabetes & 3.051 & 2.51 & 3.707 & $<0.0001$ \\
\hline Taste vs. non-taste ${ }^{8}$ & 24.636 & 17.144 & 35.404 & $<0.0001$ \\
\hline Circulatory vs. non-circulatory & 2.951 & 2.571 & 3.388 & $<0.0001$ \\
\hline Taste vs. non-taste ${ }^{9}$ & 39.451 & 27.569 & 56.454 & $<0.0001$ \\
\hline Smoke vs. never & 0.954 & 0.804 & 1.131 & 0.5872 \\
\hline
\end{tabular}

Model marked with $*$ is a raw model evaluate the association between COVID-19 status with taste and smell without adjusting for any covariate

Models 1, 2, 3, 4, 5, 6, 7, 8, and 9 have been adjusted for gender, race, age, respiratory disease, endocrine, obesity, diabetes, circulatory disease, and smoking one at a time
When adjusted for race, we found that the odds ratio of having COVID-19 for people with loss of taste and smell was 34.2 of the odds for people without taste and smell. Among this subcategory, we found that African Americans had the highest odds (OR: 2.683) of having COVID-19. Also, when we compared the African American ethnicity between the hospital population group and the COVID-19 patient group, we found a significant difference between the two groups, $11.3 \%$ among the hospital population group while $25.6 \%$ among the COVID-19 patient group. Our explanation for this finding is mainly due to the low socioeconomic status and difficulty accessing care among this patient population. Very few reports have looked into different race groups and the incidence of taste and smell disturbances among COVID-19 patients (Table 3). A study conducted by 12 European hospitals showed the number of COVID-19 patients being predominantly of European race (93\%), followed by South American $(2.7 \%)$, Sub-Saharan African (2.2\%), and African Americans (1.4\%). However, they did not correlate the association between race and loss of taste and smell in COVID-19 patients [17].

After adjusting the odds ratio for age, we found the odds for having COVID-19 for people with loss of taste and smell was 37 times the odds for people without loss of taste and smell.

Interestingly, most affected individuals were in the age group between 18-34 years (OR: 8.748). This finding is similar to a study conducted by Lee et al. [19]. This could indicate that this segment of the population, for some reason, is more susceptible to the neurotoxic effect of the virus on the chemoreceptors. When OR was adjusted for gender, we found no significant difference between males and females. This is in contrast to a study by Lee et al. [19], which showed that among COVID-19 
Table 3 Summary of the literature on the association between dysgeusia and anosmia in COVID-19 patients

\begin{tabular}{|c|c|c|c|c|c|c|c|c|}
\hline First authors & Country & $\begin{array}{l}\text { Diagnosis } \\
\text { methods }\end{array}$ & Sample size & $\begin{array}{l}\text { Prevalence } \\
\text { of OS and } \\
\text { GS }\end{array}$ & Mean age & Female proportion & $\begin{array}{l}\text { Most common } \\
\text { associated } \\
\text { comorbidities }\end{array}$ & Race \\
\hline $\begin{array}{l}\text { Dell' Era V } \\
\text { [9] }\end{array}$ & Italy & $\begin{array}{r}\text { Questionnaire/ } \\
\text { self-reported }\end{array}$ & 355 & $70 \%$ & $\begin{array}{l}49 \mathrm{OS} \\
51 \mathrm{GS}\end{array}$ & $\begin{array}{l}48.5 \% \text { OS } \\
47.4 \% \text { GS }\end{array}$ & $\begin{array}{l}\text { CVS }(31 \%) \text { in } \\
\text { OS group } \\
\text { CVS and res- } \\
\text { piratory } 30 \% \\
\text { each in the } \\
\text { GS group }\end{array}$ & Unknown \\
\hline Vaira LA [10] & Italy & Objective & 72 & $73.6 \%$ & $49.9 *$ & $62.5 \% *$ & $\begin{array}{l}\text { Pneumonia } \\
30 \% *\end{array}$ & Unknown \\
\hline Lechien J [17] & $\begin{array}{l}\text { European } \\
\text { countries }\end{array}$ & $\begin{array}{l}\text { Questionnaire/ } \\
\text { self-reported }\end{array}$ & 417 & $\begin{array}{l}85 \% \text { OS } \\
88.8 \% \text { GS }\end{array}$ & $36.9 *$ & $63.1 \% *$ & $\begin{array}{l}\text { Allergic } \\
\text { rhinitis } \\
15.7 \% *\end{array}$ & European $93 \% *$ \\
\hline Ling Mao [18] & China & Objective & 214 & $\begin{array}{l}5.1 \% \text { OS } \\
5.6 \% \text { GS }\end{array}$ & $52.2 *$ & $60.3 \% *$ & CVS $23.8 \% *$ & Unknown \\
\hline $\begin{array}{l}\text { Giacomelli A } \\
\text { [11] }\end{array}$ & Italy & $\begin{array}{l}\text { Questionnaire/ } \\
\text { self-reported }\end{array}$ & 59 & $34 \%$ & 56 & 52.6 & Unknown & Unknown \\
\hline Bagheri [12] & Iran & $\begin{array}{r}\text { Questionnaire/ } \\
\text { self-reported }\end{array}$ & $10,069^{\wedge}$ & $48.2 \%$ & 32.5 & $71 \%$ & Unknown & Unknown \\
\hline Menni [13] & UK & $\begin{array}{r}\text { Questionnaire/ } \\
\text { self-reported }\end{array}$ & 579 & $59.4 \%$ & $40.79 \pm 11.84^{*}$ & $69 \% *$ & Unknown & Unknown \\
\hline Yan [14] & USA & $\begin{array}{r}\text { Questionnaire/ } \\
\text { self-reported }\end{array}$ & 59 & $\begin{array}{l}67.8 \% \text { OS } \\
71.2 \% \text { GS }\end{array}$ & $17.6^{*}$ & $49.2 \% *$ & $\begin{array}{l}\text { Allergic } \\
\text { rhinitis } \\
33.9 \% *\end{array}$ & Unknown \\
\hline Spinato [15] & UK & $\begin{array}{r}\text { Questionnaire/ } \\
\text { self-reported }\end{array}$ & 202 & $65 \%$ & $56^{*}$ & $52 \% *$ & Unknown & Unknown \\
\hline $\begin{array}{l}\text { Giuseppe Mer- } \\
\text { cante [26] }\end{array}$ & Italy & $\begin{array}{r}\text { Questionnaire/ } \\
\text { self-reported }\end{array}$ & 204 & $56.9 \%$ & $52.6 \pm 14.4 *$ & $\begin{array}{l}\text { More prevalent } \\
\text { in female }\end{array}$ & CVS $24 \% *$ & Unknown \\
\hline $\begin{array}{l}\text { Yonghyn Lee } \\
{[19]}\end{array}$ & Korea & $\begin{array}{r}\text { Questionnaire/ } \\
\text { self-reported }\end{array}$ & 3191 & $15.3 \%$ & Median 36.5 & $68.9 \%$ & CVS & Unknown \\
\hline $\begin{array}{l}\text { Shima Moein } \\
\text { [20] }\end{array}$ & Iran & $\begin{array}{l}\text { UPSIT assisted } \\
\text { by a trained } \\
\text { examiner }\end{array}$ & 60 & $35 \%$ & $46.5^{*}$ & $33.3 \% *$ & $13 \%$ diabetes* & Unknown \\
\hline Levinson [21] & Israel & $\begin{array}{r}\text { Questionnaire/ } \\
\text { self-reported }\end{array}$ & 42 & $\begin{array}{l}35 \% \text { OS } \\
33 \% \text { GS }\end{array}$ & $34 *$ & $45 \% *$ & $\begin{array}{l}24 \% \text { cardio- } \\
\text { vascular* }\end{array}$ & Unknown \\
\hline $\begin{array}{l}\text { Daniel H. } \\
\text { Coelho [23] }\end{array}$ & USA & $\begin{array}{r}\text { Questionnaire/ } \\
\text { self-reported }\end{array}$ & $220^{\wedge}$ & Unknown & Unknown & $78.2 \%$ & $\begin{array}{l}\text { Allergic } \\
\text { rhinitis } \\
34 \%\end{array}$ & White $82 \%$ \\
\hline $\begin{array}{l}\text { Evan R. Reiter } \\
\text { [22] }\end{array}$ & USA & $\begin{array}{l}\text { Questionnaire/ } \\
\text { self-reported }\end{array}$ & $549^{\wedge}$ & Unknown & Unknown & $76.7 \%$ & Unknown & White $78.7 \%$ \\
\hline
\end{tabular}

OS, olfactory symptoms; GS, gustatory symptoms; CVS, cardiovascular system; University of Pennsylvania Smell Identification Test

*Among all COVID-19 patients

${ }^{\wedge}$ Sample size was not confirmed by laboratory testing

patients, the prevalence of loss of taste and/or smell was more common in females than in males. The susceptibility of females to develop olfactory and gustatory dysfunctions could explain the differences in the inflammatory reaction process between the two genders [25]. Among all COVID-19 patients, multiple studies (Table 3) have shown that the prevalence of COVID-19 was more common in females than in males $[17,18,26]$.

The association between COVID-19 and other similar comorbidities was reported by multiple studies $[9,10$, $14,17-21,26]$.
In our studies, after adjustment for smell and taste disturbances, the comorbidities respiratory diseases and obesity had a significant OR for COVID-19 of 8.1 and 5.3, respectively.

These risk factors and others are known comorbidities responsible for the high death rate in COVID-19 [27, 28].

As the pandemic started in December 2019, both patients and clinicians ignored taste and smell disturbances until some studies indicated a strong association between taste and smell disturbances and COVID-19. 
The prevalence of loss of smell and loss of taste in COVID-19 patients varied widely among these studies, with prevalence ranging from $33.9 \%$ to $68 \%[11,13,14$, 16].

However, a significant limitation associated with these reports is that either all of them were either self-reported by the patients or a survey filled out by the patients over the phone or online.

Only few reports, have diagnosed dysgeusia and anosmia based on physical examination, unlike the majority of the studies, which included dysgeusia and anosmia in their studies based on self-reported by the patients or a survey filled out by the patients over the phone or online (Table 3 ). Moreover, some studies have not even tested the patients to confirm the diagnosis of COVID-19 they assumed that those patients were COVID-19 positive based on the symptoms [12].

Some studies have reported that taste and smell disturbances were the only symptoms of COVID-19 [29, 30]; in these cases, patients do not have the classic sign and symptoms of COVID-19, e.g., lower respiratory tract infection, including fever, cough, and shortness. As a result, there might have been a delay in the diagnosis, as both patients and clinicians were not aware of these symptoms as part of COVID-19. Also, those patients will spread the diseases faster as they are socializing with other healthy people and an increased in the rate of transmission of COVID-19 occurred.

The exact pathophysiology of developing taste and smell disturbances with COVID-19 infection is still unclear.

Changes in smell and taste caused by virus infections like parainfluenza, rhinovirus, some coronavirus, and EpsteinBarr virus are well established in the literature. Rhinorrhea has always been associated with those viruses [31, 32]. However, anosmia in COVID-19 patients is not associated with rhinorrhea, making it different from the other causative agents.

Studies have shown that 2019-nCoV can attach to the human angiotensin-converting enzyme 2 (ACE-2), which is the same entry receptor for SARS-CoV [6]. Hamming et al. have demonstrated in their study that the ACE-2 receptors are expressed in multiple organs includes the basal epidermal layer of the oral and nasal mucosa and the nervous system [33, 34]. This could explain that this virus would cause taste and smell disturbances either by local damage of oral or nasal mucosa or by the neurotoxic effect to these nerve endings. Multiple reports have shown that coronaviruses are known to be neurotropic and neuroinvasive [18, 32, 35, 36]. Another study by Netland et al. demonstrated that SARS-CoV might lead to rapid transneuronal spread by entering the brain through the olfactory bulb [37].
Based on the observation that SARS-CoV-2 does not appear to cause clinically significant nasal congestion or rhinorrhea nor significant oral inflammation, it seems reasonable to hypothesize that the direct or neurotropic effect of the virus on the olfactory and taste receptors can lead to developing anosmia and dysgeusia. This assumption is in accordance with a study published by Xydakis et al. [38], which assumed that the virus is site-specific for the olfactory system.

Oral and maxillofacial surgeons, especially, are at increased risk of COVID-19 infection. This profession requires close contact with the patients during physical examinations, especially given the high risk of encountering aerosolized viral particles while using instruments to examine and treat the oral cavity. Based on our findings, there is an association between taste and smell disturbances and COVID-19. Therefore, we recommend that any specialists focused on the head and neck region (oral and maxillofacial surgeon, dentists, ophthalmologist, otolaryngologists, and head-neck surgeons) to include olfactory and gustatory assessment in their physical examination. Patients with sudden symptoms of taste and smell disturbances should be suspected to have COVID-19.

Further investigation for COVID-19 should be performed to avoid delaying the diagnosis of COVID19 and thus contributing to an epidemic. In conclusion, In the present study, we have found a significant association between taste and smell disturbances and COVID-19 infection. The odds ratio for having COVID-19 for people with taste and smell was 39.1 before adjustments. Our study findings support the addition of anosmia and dysgeusia to the list of screening tools for COVID-19 infection. Oral and maxillofacial surgeons should be suspicious of COVID19 infection when seeing patients experiencing smell and taste disturbances and should enhance their personnel protective equipment when treating them during the COVID19 pandemic.

Acknowledgments We acknowledge the UF Integrated Data Repository (IDR) and the UF Health Office of the Chief Data Officer for providing the analytic data sets for this project. Additionally, the research reported in this publication was supported by the National Center for Advancing Translational Sciences of the National Institutes of Health under the University of Florida Clinical and Translational Science Awards UL1 TR000064 and UL1TR00142

\section{Declarations}

Ethical approval The was IRB exempted as it did not include personal health information (PHI).

Informed consent Not applicable.

Conflict of interest There is conflict of interest. 


\section{References}

1. Lu H, Stratton CW, Tang YW (2020) Outbreak of pneumonia of unknown etiology in Wuhan, China: the mystery and the miracle, (in eng). J Med Virol 92(4):401-402. https://doi.org/10.1002/jmv. 25678

2. Danielli S, Patria R, Donnelly P, Ashrafian H, and Darzi A (2020) Economic interventions to ameliorate the impact of COVID-19 on the economy and health: an international comparison, (in eng). $\mathbf{J}$ Public Health (Oxf). https://doi.org/10.1093/pubmed/fdaa104

3. Chan J et al (2020) A familial cluster of pneumonia associated with the 2019 novel coronavirus indicating person-to-person transmission: a study of a family cluster, (in English). Lancet Article 395(10223):514-523. https://doi.org/10.1016/S0140-6736(20) 30154-9

4. Chan JYK, Wong EWY, Lam W (2020) Practical aspects of otolaryngologic clinical services during the 2019 novel coronavirus epidemic: an experience in Hong Kong. JAMA Otolaryngol Head Neck Surg 146(6):519-520. https://doi.org/10.1001/jamaoto.2020. 0488

5. Kulcsar MA, Montenegro FL, Arap SS, Tavares MR, Kowalski LP (2020) High risk of COVID-19 infection for head and neck surgeons, (in eng). Int Arch Otorhinolaryngol 24(2):e129-e130

6. Baghizadeh Fini M (2020) What dentists need to know about COVID-19, (in eng). Oral Oncol 105:104741-104741. https:// doi.org/10.1016/j.oraloncology.2020.104741

7. Young BE et al (2020) Epidemiologic features and clinical course of patients infected with SARS-CoV-2 in Singapore, (in eng). JAMA 323(15):1488-1494. https://doi.org/10.1001/jama.2020. 3204

8. Wan S et al (2020) Clinical features and treatment of COVID19 patients in northeast Chongqing. J Med Virol 92(7):797-806. https://doi.org/10.1002/jmv.25783

9. Dell'Era V, Farri F, Garzaro G, Gatto M, Aluffi Valletti P, Garzaro M (2020) Smell and taste disorders during COVID-19 outbreak: cross-sectional study on 355 patients, (in eng). Head Neck 42(7):1591-1596. https://doi.org/10.1002/hed.26288

10. Vaira LA et al (2020) Objective evaluation of anosmia and ageusia in COVID-19 patients: single-center experience on 72 cases. Head Neck 42(6):1252-1258. https://doi.org/10.1002/hed.26204

11. Giacomelli A et al (2020) Self-reported olfactory and taste disorders in patients with severe acute respiratory coronavirus 2 infection: a cross-sectional study. Clin Infect Dis 71(15):889-890. https://doi.org/10.1093/cid/ciaa330

12. Bagheri SHR et al (2020) Coincidence of COVID-19 epidemic and olfactory dysfunction outbreak. medRxiv. 2020.03.23.20041889. https://doi.org/10.1101/2020.03.23.20041889

13. Menni C et al (2020) Loss of smell and taste in combination with other symptoms is a strong predictor of COVID-19 infection. medRxiv. 2020.04.05.20048421. https://doi.org/10.1101/2020. 04.05.20048421

14. Yan CH, Faraji F, Prajapati DP, Boone CE, DeConde AS (2020) Association of chemosensory dysfunction and COVID-19 in patients presenting with influenza-like symptoms. Int Forum Allergy Rhinol 10(7):806-813. https://doi.org/10.1002/alr.22579

15. Spinato $G$ et al (2020) Alterations in smell or taste in mildly symptomatic outpatients with SARS-CoV-2 infection, (in eng). JAMA 323(20):2089-2090. https://doi.org/10.1001/jama.2020. 6771

16. Meng X, Deng Y, Dai Z, Meng Z (2020) COVID-19 and anosmia: A review based on up-to-date knowledge, (in eng). Am J Otolaryngol 41(5):102581-102581. https://doi.org/10.1016/j.amjoto. 2020.102581

17. Lechien JR et al (2020) Olfactory and gustatory dysfunctions as a clinical presentation of mild-to-moderate forms of the coronavirus disease (COVID-19): a multicenter European study, (in eng). Eur Arch Otorhinolaryngol 277(8):2251-2261. https://doi.org/10. 1007/s00405-020-05965-1

18. Mao L et al (2020) Neurologic manifestations of hospitalized patients with coronavirus disease 2019 in Wuhan, China, (in eng). JAMA Neurol 77(6):1-9. https://doi.org/10.1001/jaman eurol.2020.1127

19. Lee Y, Min P, Lee S, Kim SW (2020) Prevalence and duration of acute loss of smell or taste in COVID-19 patients, (in eng). J Korean Med Sci 35(18):e174. https://doi.org/10.3346/jkms.2020. 35.e174

20. Moein ST, Hashemian SM, Mansourafshar B, Khorram-Tousi A, Tabarsi P, Doty RL (2020) Smell dysfunction: a biomarker for COVID-19. Int Forum Allergy Rhinol 10(8):944-950. https://doi. org/10.1002/alr.22587

21. Levinson $\mathrm{R}$ et al (2020) Anosmia and dysgeusia in patients with mild SARS-CoV-2 infection. medRxiv. 2020.04.11.20055483. https://doi.org/10.1101/2020.04.11.20055483

22. Reiter ER, Coelho DH, Kons ZA, Costanzo RM (2020) Subjective smell and taste changes during the COVID-19 pandemic: short term recovery, (in eng). Am J Otolaryngol 41(6):102639-102639. https://doi.org/10.1016/j.amjoto.2020.102639

23. Coelho DH, Kons ZA, Costanzo RM, Reiter ER (2020) Subjective changes in smell and taste during the COVID-19 pandemic: a national survey-preliminary results, (in eng). Otolaryngol Head Neck Surg 163(2):302-306. https://doi.org/10.1177/0194599820 929957

24. Gane SB, Kelly C, Hopkins C (2020) Isolated sudden onset anosmia in COVID-19 infection. A novel syndrome? (ineng). Rhinology 58(3):299-301. https://doi.org/10.4193/Rhin20.114

25. Lefèvre $\mathrm{N}$ et al (2019) The number of $\mathrm{X}$ chromosomes influences inflammatory cytokine production following Toll-like receptor stimulation, (in eng). Front Immunol 10:1052-1052. https://doi. org/10.3389/fimmu.2019.01052

26. Mercante $\mathrm{G}$ et al (2020) Prevalence of taste and smell dysfunction in coronavirus disease 2019. JAMA Otolaryngol Head Neck Surg 146(8):723-728. https://doi.org/10.1001/jamaoto.2020.1155

27. Rottoli M et al (2020) How important is obesity as a risk factor for respiratory failure, intensive care admission and death in hospitalised COVID-19 patients? Results from a single Italian centre, (in eng). Eur J Endocrinol 183(4):389-397. https://doi.org/10.1530/ eje-20-0541

28. Sanchez-Ramirez DC, Mackey D (2020) Underlying respiratory diseases, specifically COPD, and smoking are associated with severe COVID-19 outcomes: A systematic review and metaanalysis, (in eng). Respir Med 171:106096. https://doi.org/10. 1016/j.rmed.2020.106096

29. Hjelmesæth J and Skaare D (2020) Loss of smell or taste as the only symptom of COVID-19, (in engnor). Tidsskr Nor Laegeforen 140(7). https://doi.org/10.4045/tidsskr.20.0287. Covid-19 med nedsatt lukte- og smakssans som eneste symptom

30. Gautier JF, Ravussin Y (2020) A new symptom of COVID-19: loss of taste and smell, (in eng). Obesity (Silver Spring) 28(5):848. https://doi.org/10.1002/oby.22809

31. van Riel D, Verdijk R, Kuiken T (2015) The olfactory nerve: a shortcut for influenza and other viral diseases into the central nervous system. J Pathol 235(2):277-287. https://doi.org/10.1002/ path.4461

32. Suzuki $M$ et al (2007) Identification of viruses in patients with postviral olfactory dysfunction, (in eng). Laryngoscope 117(2):272-277. https://doi.org/10.1097/01.mlg.0000249922. $37381.1 \mathrm{e}$

33. Hamming I, Timens W, Bulthuis MLC, Lely AT, Navis GJ, van Goor H (2004) Tissue distribution of ACE2 protein, the functional receptor for SARS coronavirus. A first step in understanding 
SARS pathogenesis, (in eng). J Pathol 203(2):631-637. https:// doi.org/10.1002/path.1570

34. Sakaguchi W, Kubota N, Shimizu T, Saruta J, Fuchida S, Kawata A, Yamamoto Y, Sugimoto M, Yakeishi M, Tsukinoki K (2020) Existence of SARS-CoV-2 entry molecules in the oral cavity. Existence of SARS-CoV-2 Entry Molecules in the Oral Cavity. Int J Mol Sci 21:6000

35. Desforges M, Le Coupanec A, Brison E, Meessen-Pinard M, Talbot PJ (2014) Neuroinvasive and neurotropic human respiratory coronaviruses: potential neurovirulent agents in humans, (in eng). Adv Exp Med Biol 807:75-96. https://doi.org/10.1007/ 978-81-322-1777-0_6

36. Li Y-C, Bai W-Z, Hashikawa T (2020) The neuroinvasive potential of SARS-CoV2 may play a role in the respiratory failure of
COVID-19 patients, (in eng). J Med Virol 92(6):552-555. https:// doi.org/10.1002/jmv.25728

37. Netland J, Meyerholz DK, Moore S, Cassell M, Perlman S (2008) Severe acute respiratory syndrome coronavirus infection causes neuronal death in the absence of encephalitis in mice transgenic for human ACE2, (in eng). J Virol 82(15):7264-7275. https://doi. org/10.1128/jvi.00737-08

38. Xydakis MS et al (2020) Smell and taste dysfunction in patients with COVID-19, (in eng). Lancet Infect Dis 20(9):1015-1016. https://doi.org/10.1016/s1473-3099(20)30293-0

Publisher's note Springer Nature remains neutral with regard to jurisdictional claims in published maps and institutional affiliations. 